\title{
ZONASI DAN KOMPOSISI VEGETASI HUTAN MANGROVE PANTAI CENGKRONG DESA KARANGGANDU KABUPATEN TRENGGALEK PROVINSI JAWA TIMUR
}

\section{Zonation and Composition of Mangrove Forest Vegetation at Coast Cengkrong, Cengkrong Village, District of Karanggandu, Trenggalek East Jawa Provinsi}

\author{
Ahmad Mughofar ${ }^{\mathrm{a}}$, Mohammad Masykuri ${ }^{\mathrm{b}}$, Prabang Setyono ${ }^{\mathrm{c}}$ \\ ${ }^{a}$ Pascasarjana Ilmu Lingkungan, Universitas Sebelas Maret, Jl. Ir. Sutami 36 A Surakarta 57126, Jawa Tengah, \\ Indonesia —ahmadpastibisa5@gmail.com \\ ${ }^{b}$ Program Studi Pendidikan Kimia, Fakultas Keguruan dan Ilmuu Pendidikan, Universitas Sebelas Maret, Jl. Ir. \\ Sutami 36 A Surakarta, Jawa Tengah, Indonesia \\ ${ }^{c}$ Fakultas MIPA Universitas Sebelas Maret Surakarta JL. Ir. Sutami 36 A Surakarta 57126, Jawa Tengah, Indonesia
}

\begin{abstract}
A research on mangrove forest at coast Cengkrong in the village of Karanggandu aimed at defining zoning and composition of magrove vegetation. The sampling method consists of 3 zoning. Each zone established 3 plots, consists of $10 \mathrm{~m} x 10$ $m$ plot size of trees category, $5 \mathrm{~m} \times 5 \mathrm{~m}$ of stake category, and $1 \mathrm{~m} \times 1 \mathrm{~m}$ of seedling category to repeat in 3 times. Data analysis of mangrove vegetation employed Improtance Value Indeks (IVI). The research results found 12 mangrove species namely Avicennia alba, Bruguiera gymnorrhiza, Bruguiera parviflora, Ceriops decandra, Ceriops tagal, Lumnitczera racemosa, Rhizophora apiculata, Rhizophora mucronata, Sonneratia alba, Sonneratia caseolaris, Xylocarpus granatum Nypa fruticans. Reffering to the the mangrove zonation indicates the zone I or open zone grows Sonneratia alba and it can be found Rhizophora mucronata, Ceriops decandra with salinity of 6 ppt. Zone II or middle zone grows species of Avicennia alba and it also be found Sonneratia alba, Xylocarpus granatum with salinity of 6 ppt. Zone III or zone that is closer to the landward grows species Xylocarpus granatum and also appears Lumnitzera racemosa,Bruguiera parviflora with salinity of 4 ppt. It showed that the formation of mangrove zonation at Coast Cengkrong is still categorized as less stable, due to rehabilitation since 2002 were done without understanding the type of site suitability and natural factors which causes the fruits drop when the tides of sea water, so that the growth is not stable.
\end{abstract}

Keywords: Composition, mangrove, zonation

(Diterima: 10-03-2017; Disetujui: 20-06-2017)

\section{Pendahuluan}

\subsection{Latar Belakang}

Hutan Mangrove Pancer Cengkrong adalah sebuah cagar alam hutan mangrove atau hutan bakau yang lokasinya hanya berjarak 500 meter dari pesisisr pantai kawasan Cengkrong di Kabupaten Trenggalek, Jawa

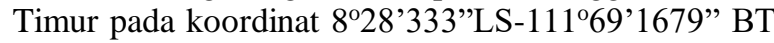
dengan luas area hutan mangrove mencapai 87 hektar (BPS, 2016). Mangrove merupakan nama kelompok tumbuhan yang hidup di daerah pantai, beriklim tropis, substrat berlumpur, dan lahan terhadap salinitas (Chandra et al., 2011). Hutan mangrove yang dimulai dari arah laut kearah daratan yang disebut dengan zonasi mangrove. Zonasi hutan mangrove terdiri dari tiga bagian antara lain zonasi dekat dengan laut, zonasi antara laut dan darat, zonasi dekat dengan darat, namun selain berdasarkan letaknya pembagian zonasi mangrove juga berdasarkan pada tumbuhan penyusunnya. Setiap ekosistem mangrove memiliki zonasi yang berbeda-beda disetiap kawasan atau pulau yang salah satunya adalah kawasan mangrove Pantai Cengkrong di Desa Karanggandu.
Ekosistem magrove bersifat dinamis, labil, dan kompleks. Ekosistem mangrove bersifat dinamis karena dapat terus tumbuh, berkembang, mengalami suksesi, dan mengalami perubahan zonasi. Ekosistem mangrove bersifat labil karena mudah sekali rusak dan sulit untuk pulih kembali. Ekosistem mangrove bersifat kompleks karena merupakan habitat berbagai jenis satwa daratan dan biota perairan (Kusmana, 1995), salah satunya makrozoobentos.

Zonasi adalah kondisi dimana kumpulan vegetasi yang saling berdekatan mempunyai sifat atau tidak ada sama sekali jenis yang sama walaupun tumbuh dalam lingkungan yang sama dimana dapat terjadi perubahan lingkungan yang dapat mengakibatkan perubahan nyata di antara kumpulan vegetasi, selanjutnya perubahan vegetasi tersebut dapat terjadi pada batas yang jelas atau tidak jelas atau bisa terjadi bersamasama (Anwar et al., 1984). Zonasi hutan mangrove sangat dipengaruhi oleh substrat, salinitas dan pasang surut. Beberapa ahli seperti Chapman (1977) dan Bunt dan Williams (1981), menyatakan bahwa hal tersebut berkaitan erat dengan tipe tanah (lumpur, pasir atau gambut), keterbukaan (terhadap hempasan gelombang), salinitas serta pangaruh pasang surut. Pasang surut dan arus yang membawa material sedimen 
dan substrat yng membawa material sedimen dan substrat yang terjadi secara priodik menyebabkan perbedaan dalam pembentukan zonasi mangrove. Menurut Kint (1934), substrat berlumpur ini sangat baik untuk tegakan Rhizophora mucronata dan Avicennia marina. Jenis-jenis lain seperti Rhizopora stylosa tumbuh dengan baik pada substrat berpasir, bahkan pada pulau karang, kerang dan bagian-bagian dari Halimeda (Ding Hou, 1985). Avicennia merupakan marga yang memiliki kemampuan toleransi terhadap kisaran salinitas yang luas dibandingkan dengan maraga lainnya. Avicenia marina mampu tumbuh dengan baik pada salinitas yang mendekati tawar sampai dengan $90 \%$ (MacNae, 1966;1968). Jenis-jenis tumbuhan mangrove ini bereaksi berbeda terhadap variasi-variasi lingkungan fisik, sehingga memunculkan zona-zona vegetasi tertentu dan zonasi dari setiap daerah memiliki pola yang berbeda-beda tergantung dari keadaan fisiografi daerah pesisir dan dinamika pasang surutnya. Beberapa faktor lingkungan fisik tersebut adalah: jenis tanah, terpaan ombak, salinitas dan penggenangan oleh air pasang. Menghadapi variasi-variasi kondisi lingkungan seperti ini, secara alami akan terbentuk zonasi vegetasi mangrove.

Diketahui bahwa zonasi yang terbentuk memiliki beberapa model yang berbeda pada setiap lokasi di setiap daerah. Sebagaimana Nyabakken (1992) menyatakan bahwa "Tidak ada model yang berlaku secara universal". Skema umum zonasi mangrove untuk penggunaan secara luas pada daerah Indo-Pasifik dapat digunakan, namun skema yang berlaku di suatu tempat dapat berbeda dengan tempat yang lainnya. Pembentukan zonasi hutan mangrove yang dipengaruhi oleh beberapa faktor lingkungan kemudian akan membentuk penyebaran jenis mangrove yang secara dominan menguasai masing-masing habitat zonasinya. Menurut Jamili (1998) vegetasi hutan mangrove di hampir setiap daerah mengalami penurunan kualitas maupun kuantitas disebabkan adanya eksploitasi oleh masyarakat yang apabila tidak terkendali maka hutanmangrove di daerah tersebut akan mengalami kerusakan. Analisis vegetasi adalah cara mempelajari susunan (komposisi jenis) dan bentuk (struktur) vegetasi atau masyarakat tumbuhan-tumbuhan (Anonim, 2006). Pentingnya analisis vegetasi dalam suatu habitat dilakukan yaitu untuk dapat mengetahui stuktur, kemelimpahan jenis, distribusi vegetasi dalam suatu ekosistem, serta hubungan keberadaan tumbuhan dengan faktor lingkungannya.

Pengetahuan masyarakat Desa Karanggandu Pantai Cengkrong tentang peranan hutan mangrove baik secara ekologi maupun ekonomi masih sangat terbatas, hal ini ditunjukkan dengan semakin menurunnya luas dan komunitas hutan mangrove yang disebabkan aktifitas masyarakat dengan mengeksploitasi hutan untuk dijadikan lahan pertambakan serta pemanfaatan pohon dari jenis mangrove sebagai bahan kayu bakar atau perabot rumah tangga dan dijadikan tempat ekowisata, sehingga menyebabkan semakin menurunnya fungsi huan mangrove. Oleh karena itu, diharapkan instansi atau lembaga terkait khususnya
Dinas Kelautan dan Perikanan (DKP) Kabupaten Trenggalek dapat melakukan sosialisasi tentang komposisi vegetasi dan pola zonasi hutan mangrove khususnya di kawasan hutan mangrove yang berada di Desa Karanggandu Pantai Cengkrong. Oleh karena itu, penulis tertarik untuk melakukan penelitian ini yang mengkaji zonasi dan komposisi vegetasi hutan mangrove Pantai Cengkrong Desa Karanggandu Kabupaten Trenggalek Provinsi Jawa Timur, sebagai langkah dalam reabilitasi, supaya dalam menanam bisa sesuai dengan pola zonasi hutan mangrove.

\subsection{Tujuan Penelitian}

Tujuan dari penelitian ini adalah untuk mengetahui zonasi dan komposisi vegetasi mangrove Pantai Cangkrong Desa Karanggandu Kecamatan Watulimo.

\section{Metode}

\subsection{Tempat dan Waktu}

Penelitian ini dilakukan di Desa Karanggandu Pantai Cengkrong Kabupaten Trenggalek. Penelitian dilaksanakan pada Tanggal 9 Desember 2016 sampai 16 Januari 2017.

\subsection{Bahan dan Alat}

Bahan yang digunakan dalam penelitian ini adalah vegetasi hutan mangrove, alumunium foil, tali rafia dan data informasi yang relevan.Alat yang digunakan dalam penelitian ini adalah latop dengan dilengkapi Microsoft Excel Word. Peralatan lainnya yang digunakan dilapangan adalah GPS, kamera, meteran, termometer dan soil tester.

\subsection{Analisis Data}

\subsubsection{Metode Zonasi Mangrove}

Pengambilan data zonasi mangrove dilakukan dengan menggunakan metode deskriptif kualitatif dan survei lapangan dengan eksploratif. Penelitian eksploratif merupakan metode penelitian yang mengkaji dan mengungkapkan sesuatu dari lapangan sebagai suatu temuan yang dapat digunakan untuk menyusun model dan menarik kesimpulan (Messerschmidt, 1995). Membagi lokasi penelitian menjadi 3 zonasi dengan cara purposive sampling. Langkah-langkah yang dilakukan:

1. setiap zonasi dibuat tiga plot yaitu dari pinggir ke bagian tengah kemudian kedalam. Kemudian setiap plot diambil data vegetasi mangrove yang meliputi, ukuran plot $10 \mathrm{~m}$ x $10 \mathrm{~m}$ untuk pohon setinggi dada $\geq 10 \mathrm{~cm}$, ukuran plot $5 \mathrm{~m} \times 5 \mathrm{~m}$ untuk pancang, ukuran $1 \mathrm{~m}$ x $1 \mathrm{~m}$ untuk semai, semak, dan herba.

2. Vegetasi yang diperoleh kemudian dihitung jumlah individu dan jumlah spesies. Spesies yang belum diketahui diidentifikasi dengan menggunakan buku Noor etal (1999). 
3. Data perhitungan mangrove seperti kerapatan, kerapatan relatif, frekuensi, frekuensi relatif, dominansi, dominansi relatif, dan Indeks nilai penting (INP).

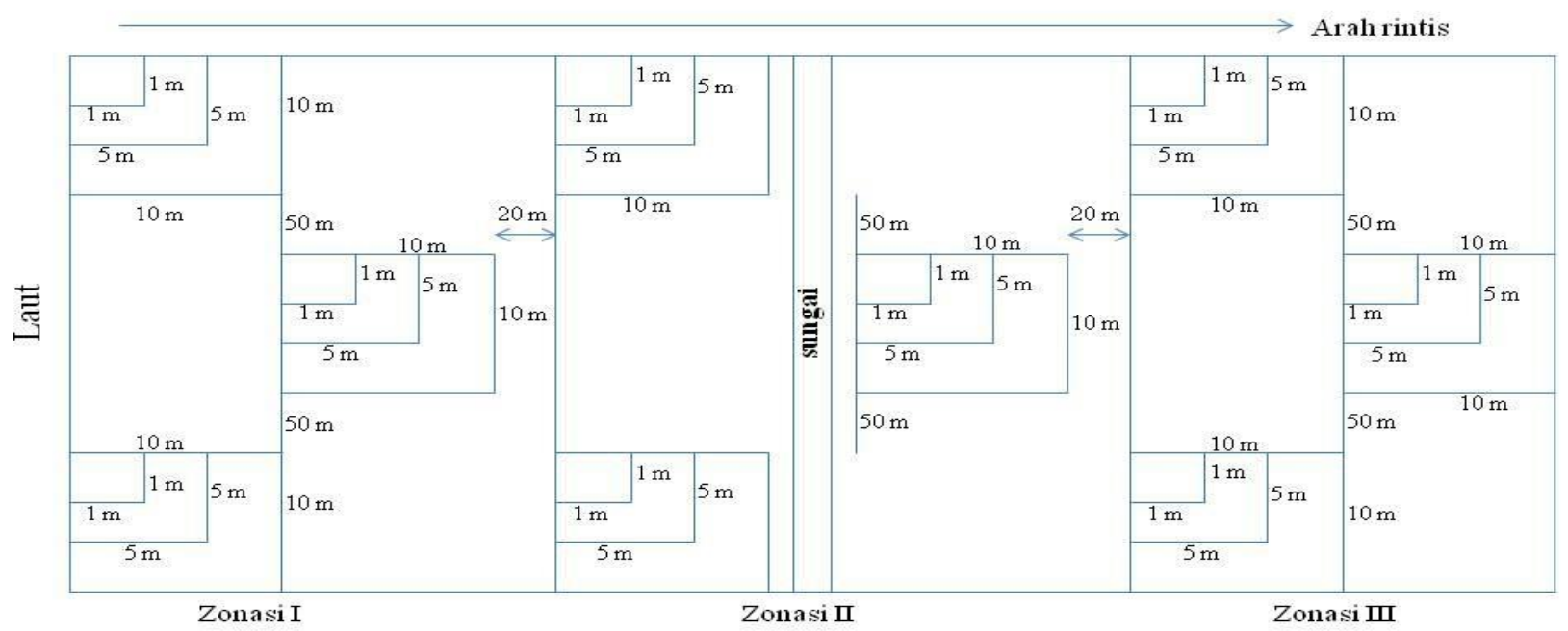

Gambar 1. Model Peletakan Plot Penelitian

\subsubsection{Vegetasi Mangrove}

Analisis vegetasi spesies mangrove dilakukan dengan menghitung Indek Nilai Penting (INP) dengan bantuan Microsoft office excel 2007 dengan rumus sebagai berikut:

Kerapatan $=\frac{\text { jumlah individu suatu spesies }}{\text { luas seluruh plot }}$

Kerapatan Relatif $=\frac{\text { kerapatan } \text { suatus pesies }}{\text { kerapatan seluruh spesies }} \times 100 \%$

Frekuensi $=\frac{\text { jumlah plot yang ditempati suatu spesies }}{\text { jumlah plot seluruh pengamatan }}$

Frekuensi Relatif $=\frac{\text { frekuensi suatu spesies }}{\text { frekuensi } \text { seluruh spesies }} \times 100 \%$

Dominansi $=\frac{\text { jumlah basal area suatu spesies }}{\text { luas seluruh plot }}$

DominansiRelatif $=\frac{\text { dominansi } \text { suatu spesies }}{\text { dominansi seluruh spesies }} \times 100 \%$

NilaiPenting(pohon dan pancang $)=K R+F R+D R$

Nilai Penting (semai, semak, dan herba) $=K R+F R$ (Krebs, 1972).

\subsubsection{Pengukuran Parameter Lingkungan}

Parameter lingkungan yang ditentukan pada masing-masing zonasi yaitu $\mathrm{pH}$ tanah, suhu udara, salinitas dan subtrat. Pada pengukuran Derajat Keasaman $(\mathrm{pH})$ digunakan alat berupa kertas lakmus dengan cara mencelupkan kertas lakmus tersebut. Pengukuran suhu udara diukur dengan menggunakan alat berupa termometer yang nantinya berfungsi untuk mengukur kondisi udara. Pada pengukuran salinitas akan diukur dengan menggunakan alat berupa refraktometer dengan cara meneteskan air yang diambil dari lokasi penelitian. Sedangkan untuk parameter lingkungan mangrove yang terakhir adalah subtrat, dimana pengukuran subtrat ini dilakukan dengan mengambil tanah lalu ditimbang berat kering basah menggunakan timbangan analitik dan dimasukan dalam oven.

\section{Hasil dan Pembahasan}

\subsection{Komposisi hutan mangrove}

Komposisi vegetasi mangrove yang ditemukan di Pantai Cengkrong Desa Karanggandu melalui hasil perhitungan Indek Nilai Penting (INP) mangrove baik tingkat pohon, pancang dan semai ditemukan sebanyak 12 (dua belas) jenis yaitu jenis Rhizophora apiculata, Rhizophora mucronata, Sonneratia alba, Sonneratia caseolaris, Ceriops decandra, Ceriops tagal, Avicennia alba, Bruguiera gymnorrhiza, Bruguiera parviflora, Xylocarpus granatum, Lumnitczera racemosa dan Nypa fruticans. Indeks Nilai Penting (INP) strata pohon, pancang dan pohon vegetasi hutan mangrove disajikan dalam Gambar 2. 


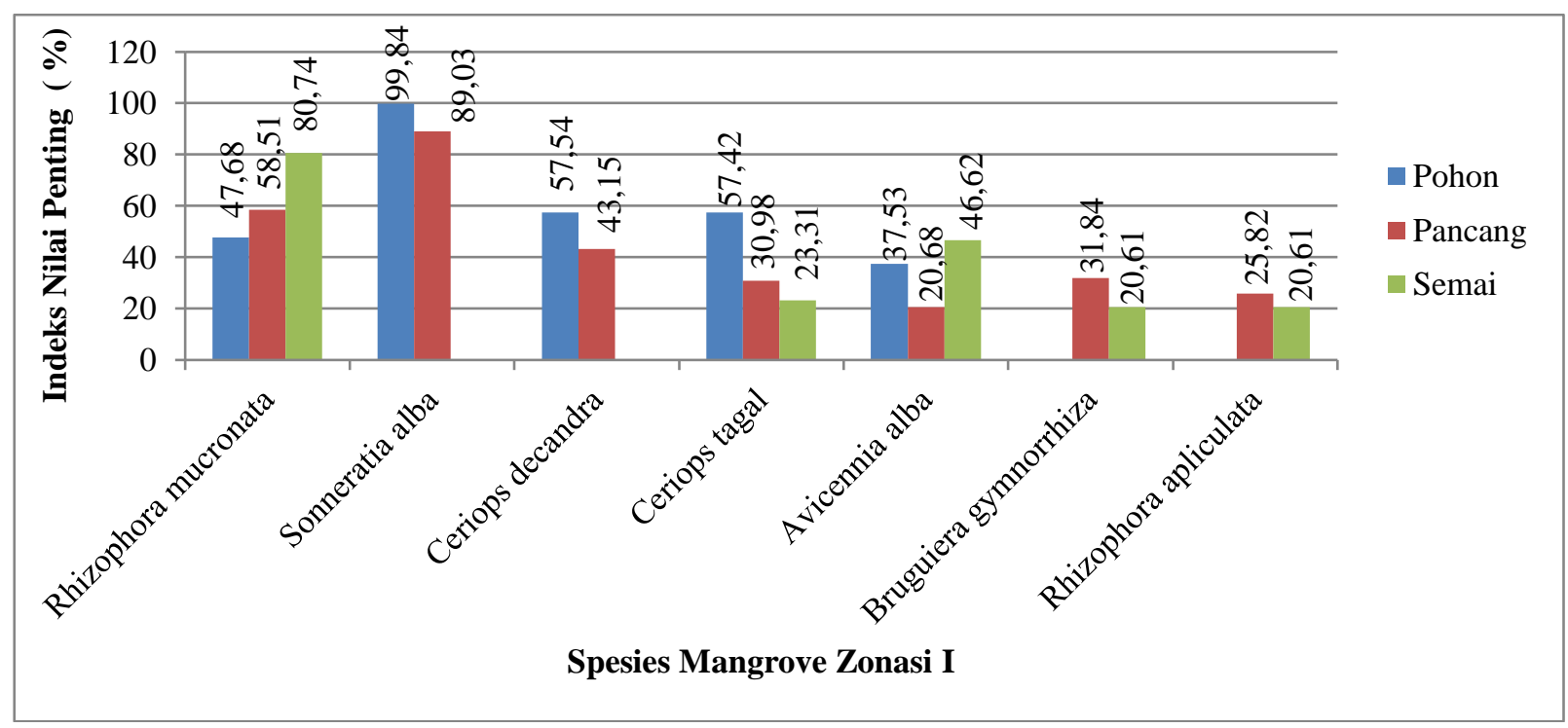

Gambar 2. Indeks Nilai Penting (INP) vegetasi mangrove zonasi I

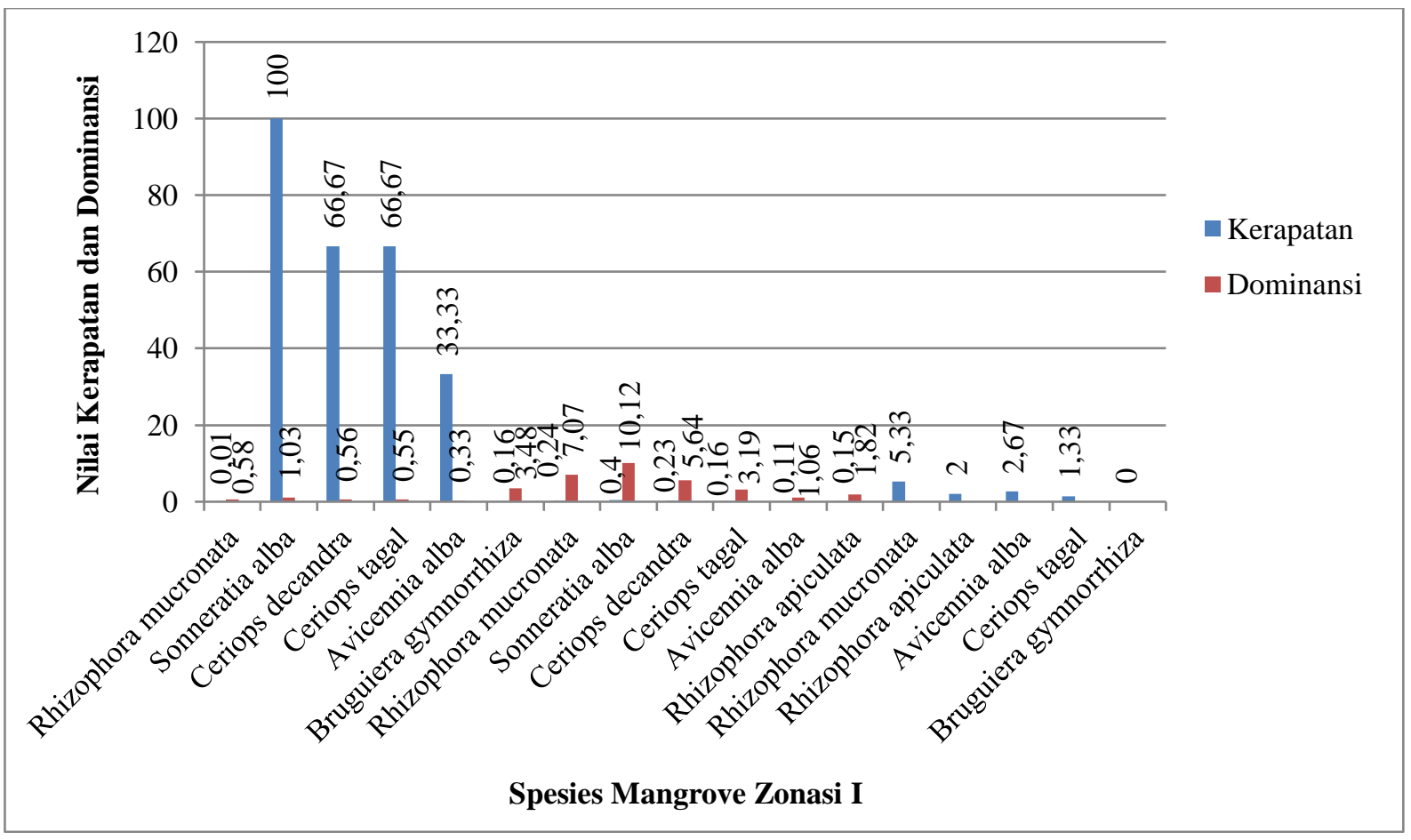

Gambar 3. Nilai kerapatan dan dominansi vegetasi mangrove zonasi I

Hasil dari Gambar 2 menunjukkan bahwa vegetasi hutan mangrove pada zonasi I telah ditemukan 7 jenis spesies yaitu Rhizophora mucronata, Sonneratia alba, Ceriops decandra, Ceriops tagal, Avicennia alba, Bruguiera gymnorrhiza dan Rhizophora apiculata. Sonneratia alba memiliki nilai INP paling tinggi pada stratum pohon sebesar 99,84\%, pancang sebesar 89,03\% dan Rhizophora mucronata sebesar 80,74\% pada stratum semai. Pada Gambar 3 kerapatan hutan magrove Pantai Cengkrong Sonneratia alba sebesar 100 dan dominansi jenis Sonneratia alba sebesar 10,12. Hal tersebut karena Sonneratia alba merupakan mangrove pionir yang mampu bertahan hidup dilokasi pantai dengan pengaruh pasang surut dan salinitas, selain itu sistem perkembangan terjadi sepanjang tahun (Noor et al. 2012).

Masyarakat jarang yang memanfaatkan kayu Sonneratia alba tetapi mereka memanfaatkan buah sebagai bahan untuk sirup sehingga keberadaan Sonneratia alba bisa terjaga oleh masyarakat. Samingan (1980) menemukan bahwa di Karang Agung Sumatra Selatan, di zona ini didominansi oleh Sonneratia alba yang tumbuh pada areal yang betulbetul dipengaruhi oleh air laut. Van Steenis (1958) melaporkan bahwa $S$. alba dan A. alba merupakan jenis-jenis ko-dominan pada areal pantai yang sangat tergenang ini. Komiyama, dkk (1988) menemukan bahwa bahwa di Halmahera, Maluku, di zona ini didominansi oleh S. alba. Menurut Bengen (2004) pada 
zonasi garis pantai atau zonasi luar biasanya ditemukan jenis Rhizophora stylosa, Rhizophora mucronata, Avicennia marina dan Avicennia alba. Madiana et al. (2016) zonasi hutan mangrove di daerah Negeri Passo menemukan jenis Sonneratia alba yang paling dominan. Jadi pada zonasi luar atau zona yang berhadapan dengan laut masih didominansi jenis Sonneratia alba.

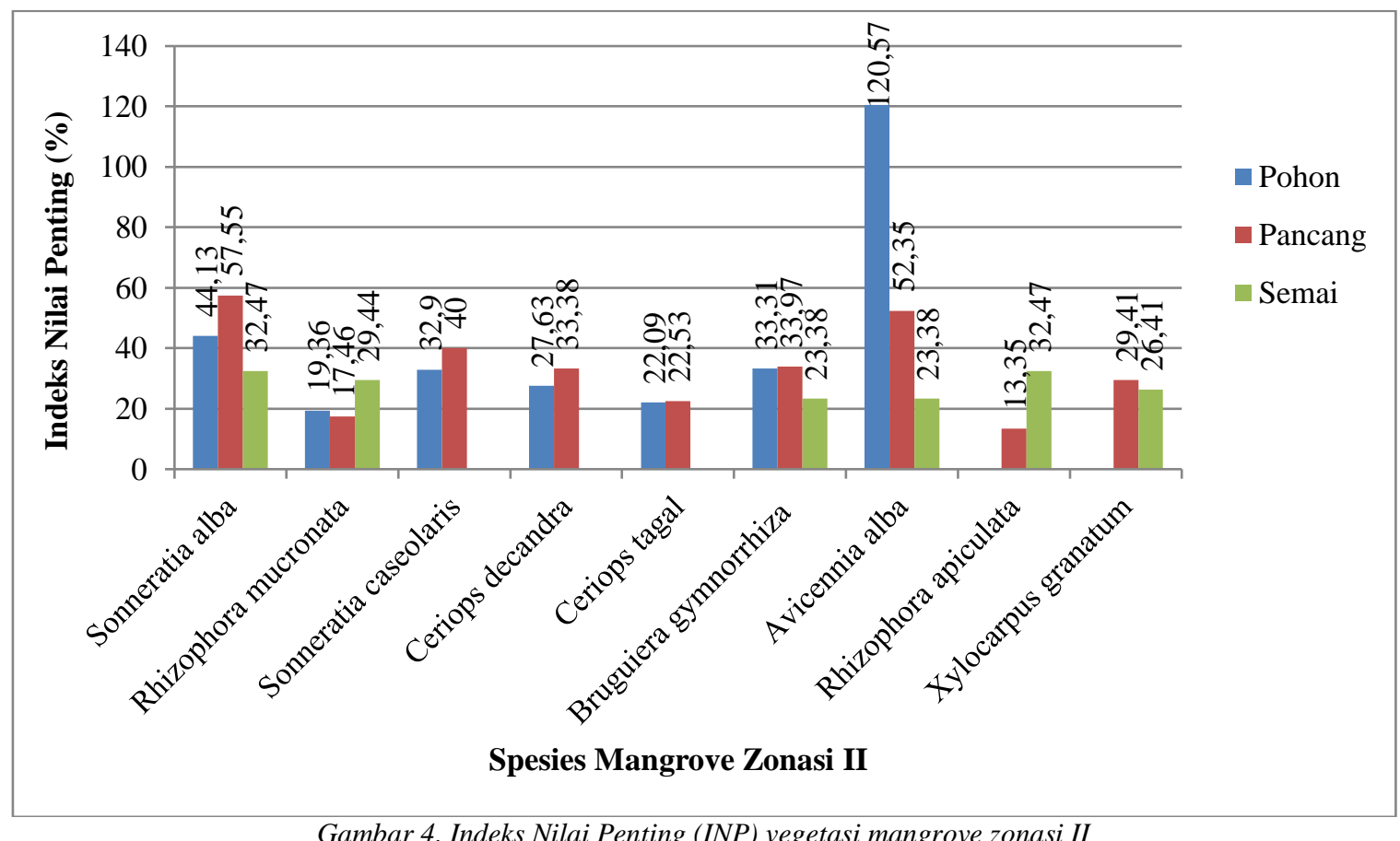

Gambar 4. Indeks Nilai Penting (INP) vegetasi mangrove zonasi II

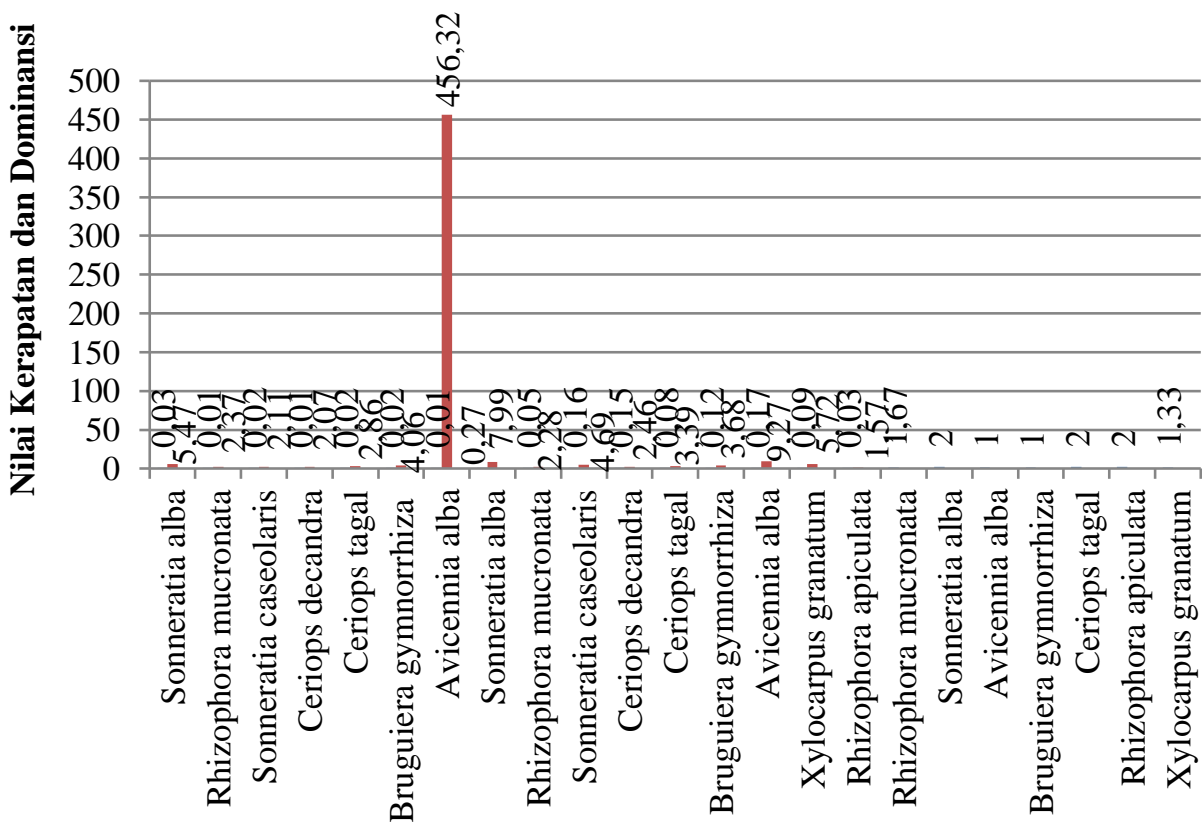

- Kerapatan

- Dominansi

Spesies Mangrove Zonasi II

Gambar 5. Nilai kerapatan dan dominansi vegetasi mangrove zonasi II

Vegetasi hutan mangrove pada Gambar 4 zonasi II telah ditemukan 9 jenis spesies yaitu Sonneratia alba, Rhizophora mucronata, Sonneratia caseolaris, Ceriops decandra, Ceriops tagal, Bruguiera gymnorrhiza, Avicennia alba, Xylocarpus granatum dan Rhizophora apiculata. Avicennia alba memiliki INP paling tinggi pada stratum pohon sebesar $120,57 \%$, Sonneratia alba pada stratum pancang sebesar $57,55 \%$ dan semai jenis spesies Sonneratia alba sebesar 32,47\%, Ceriops tagal sebesar 32,47\% dan Rhizophora apiculata 32,47\%. Avicennia alba merupakan jenis tumbuhan pionir dan oportunistik, sehingga mudah tumbuh kembali dan oleh masyarakat buahnya digunakan untuk membuat sirup yang mempunyai nilai ekonomi. Pada Gambar 5 nilai 
kerapatan yang paling tinggi jenis Sonneratia alba, Ceriops tagal, Rhizophora apiculata sebesar 2,00 dan didominansi jenis Avicennia alba sebesar 456, 32. Namun, Samingan (1980) menemukan di Karang Agung didominansi oleh Bruguiera Cylindrica. Jenis- jenis penting lainnya yang ditemukan di KArang Agung adalah B. Eriopetala, B. Gymnorrhiza, Excoecaria agallocha, R. Mucronata, Xylocarpus granatum dan X. Moluccensis.

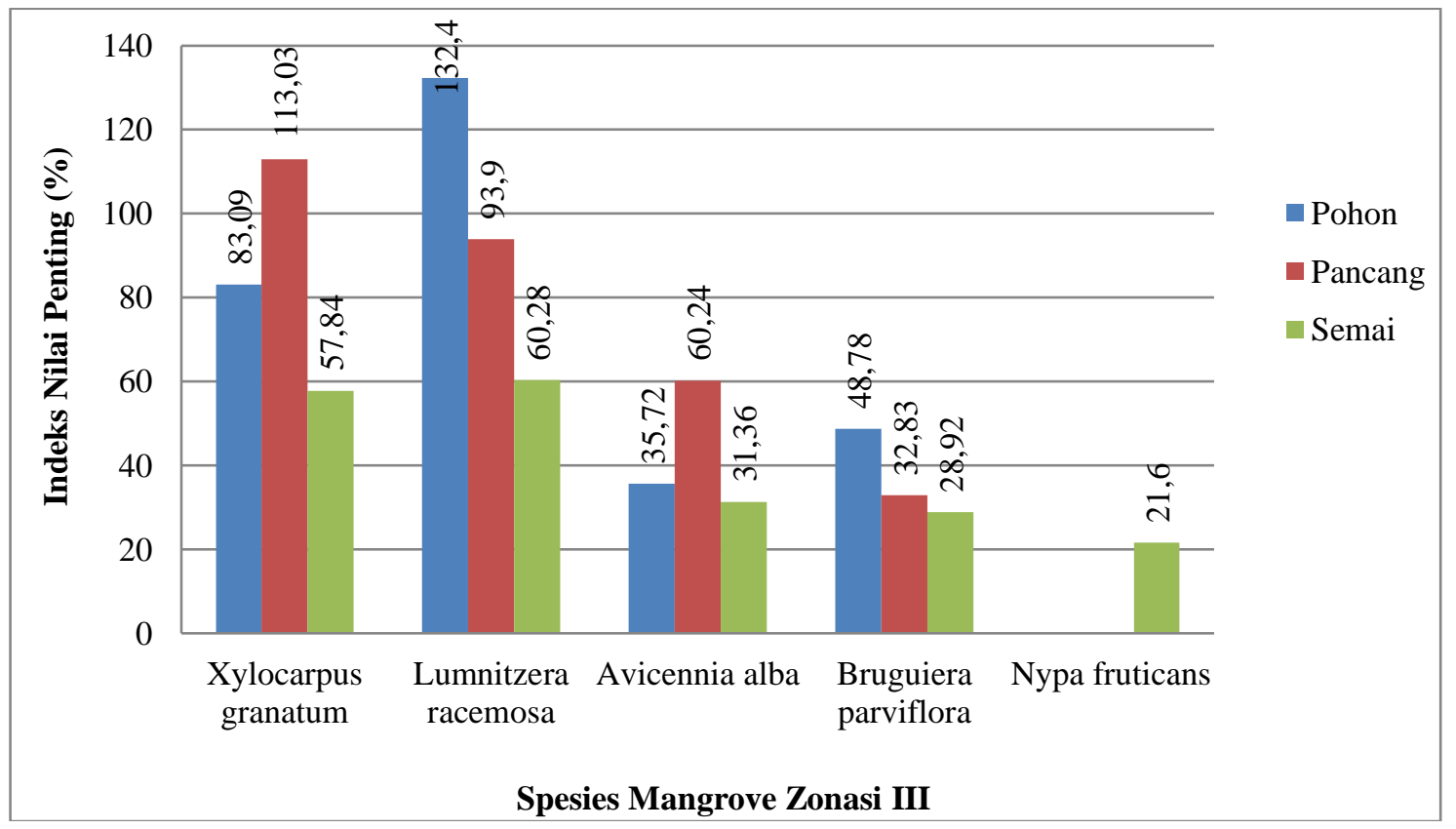

Gambar 6. Indeks Nilai Penting (INP) vegetasi mangrove zonasi III

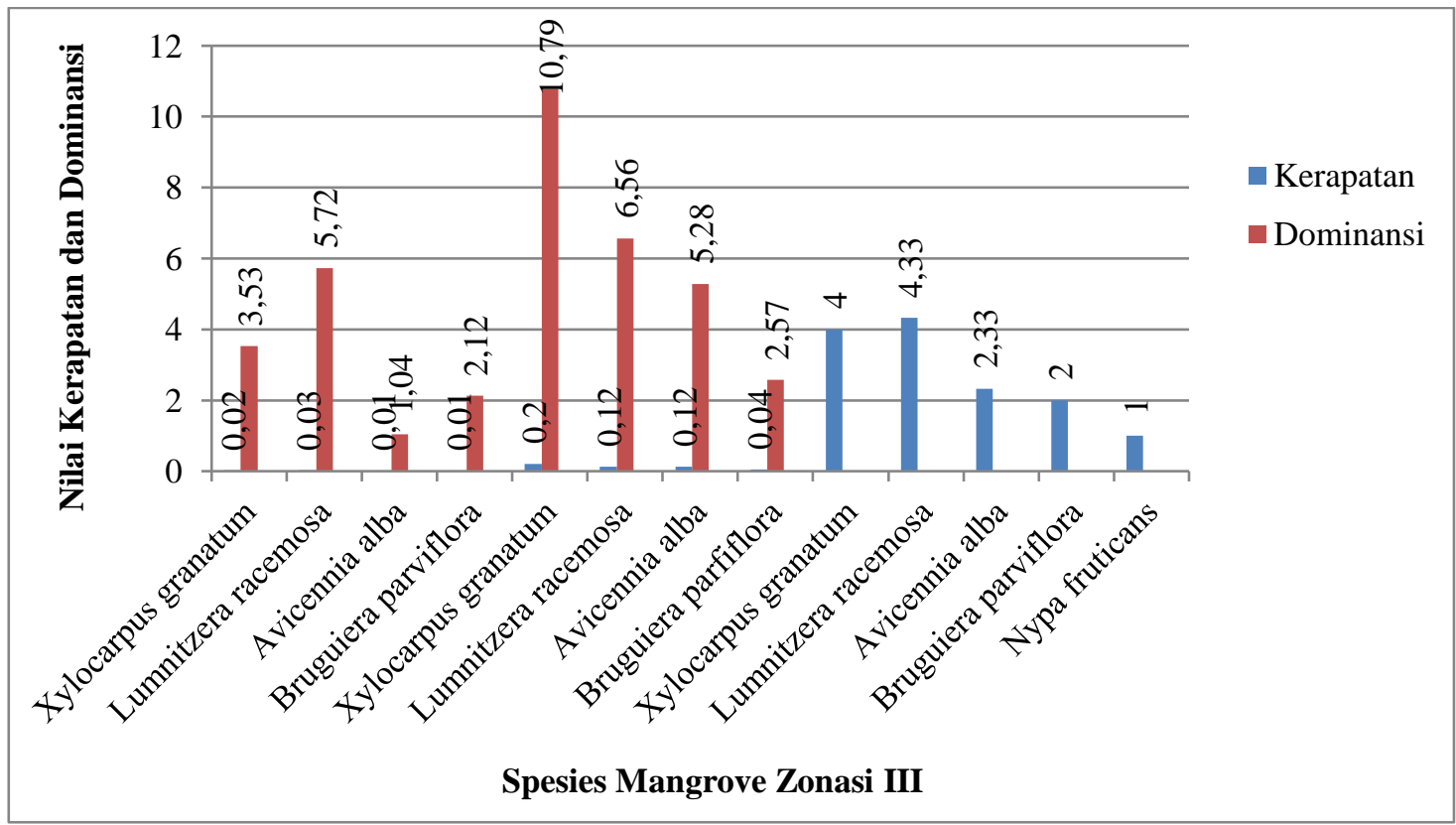

Gambar 7. Nilai kerapatan dan dominansi vegetasi mangrove zonasi II

Vegetasi hutan mangrove pada Gambar 6 stasiun III telah ditemukan 5 jenis spesies yaitu Xylocarpus granatum, Lumnitzera racemosa, Avicennia alba, Bruguiera parviflora dan Nypa fruticans. Xylocarpus granatum memiliki INP paling tinggi straum pohon sebesar $132,40 \%$, pancang $113,03 \%$ dan Lumnitzera racemosa stratum semai sebesar $60,28 \%$. Nilai kerapatan pada stasiun III yang paling tinggi terdapat jenis Lumnitzera racemosa sebesar 4,33 \% dan terendah pada jenis Avicennia alba dan Bruguiera parviflora sebesar 0,01\%. Menurut Noor $d k k$ (2006) jenis Xylocarpus granatum dapat tumbuh di sepanjang pinggiran sungai dan lingkungan payu lainnya yang tidak terlalu asin. Jenis-jenis yang umum ditemukan pada zona ini termasuk Ficus microcarpus (F. retusa), Intsia bijuga, N. fruticans, Lumnitzera racemosa, 
Pandanus sp,dan Xylocarpus moluccensis (Kantor Menteri Negara Lingkungan Hidup, 1993). Nilai kerapatan dan dominansi pada Gambar 7 menunjukkan hasil kerapatan yang paling tinggi yaitu jenis Lumnitzera racemosa sebesar 4,33 dan didominansi jenis Xylocarpus granatum sebesar 10,79. Zona ini memiliki kekayaan jenis yang lebih tinggi dibandingkan dengan zona lainnya. Meskipun kelihatanya terdapat zona dalam vegetasi mangrove, namun kenyataan di lapangan tidaklah sederhana itu. Banyak formasi serta zona vegetasi yang tumpang tindih dan bercampur serta seringkali struktur dan korelasi yang nampak di suatu daerah tidak selalu dapat diaplikasikan di daerah yang lain. Mungkin dikarenakan kondisi lingkungan dan buah yang jatuh terbawah pasang surut air laut.

\subsection{Parameter Lingkungan Hutan Mangrove}

Kondisi lingkungan di setiap zonasi penelitian pertumbuhan mangrove, baik kondisi $\mathrm{pH}$ tanah, suhu udara, salinitas dan subtrat. Kondisi lingkungan ekosistem mangrove di lokasi penelitian pada setiap zona dapat dilihat pada Tabel 1 .

\begin{tabular}{llllll}
\multicolumn{5}{c}{ Tabel 1. Parameter Lingkungan Ekosistem Mangrove Pancer Cengkrong } \\
\hline \multirow{2}{*}{ No } & Parameter Lingkungan & \multicolumn{3}{c}{ Zonasi } & III \\
\cline { 3 - 6 } & & $\mathrm{I}$ & $\mathrm{II}$ & 6,9 & 6,7 \\
\hline 1 & pH Tanah & 6,4 & 6,7 & $30^{\circ} \mathrm{C}$ & $31^{\circ} \mathrm{C}$ \\
2 & Suhu udara & $32^{\circ} \mathrm{C}$ & $31^{\circ} \mathrm{C}$ & $4 \mathrm{ppt}$ & $5,3 \mathrm{ppt}$ \\
3 & Salinitas & $6 \mathrm{ppt}$ & $6 \mathrm{ppt}$ & Liat & Liat \\
4 & Subtrat & Liat & Liat & &
\end{tabular}

Faktor lingkungan yang berpengaruh terhadap kelangsungan hidup tumbuhan mangrove adalah suplai air tawar, salinitas, pasokan nutrient, dan stabilitas substrat (Dahuri et al., 2001). Pengambilan faktor lingkungan zonasi I dilakukan pada siang hari tepatnya pukul 12:30 WIB diperoleh faktor lingkungan yang berpengaruh tinggi terhadap pertumbuhan mangrove adalah $\mathrm{pH}$ tanah $(6,4)$, suhu udara $\left(32{ }^{0} \mathrm{C}\right)$, salinitas $(6 \mathrm{ppt})$. Hal tersebut disebabkan letak zonasi I berada didekat pantai dengan intensitas cahaya matahari yang optimal, sehingga suhu udara tinggi. Pengambilan faktor lingkungan pada zonasi II dan III dilakukan pada siang hari tepatnya pukul 09:00 WIB diperoleh hasil faktor lingkungan yang berpengaruh tinggi terhadap pertumbuhan mangrove adalah salinitas (6 ppt) zonasi II. Hal tersebut dikarenakan letak zonasi II berada di sekitar sungai, namun masih mendapat aliran air laut sehingga salinitas sama zonasi I dan lebih besar zonasi III dengan nilai sebesar salinitas (4 ppt). Menurut Saputra (2003) menyatakan bahwa salinitas sebesar 222 ppt sesuai untuk pertumbuhan mangrove. Faktor lingkungan yang berpengaruh tinggi terhadap kehidupan mangrove pada zonasi III berbatasan dengan darat, namun masih mendapat genangan air payau, sehingga kondisis $\mathrm{pH}$ tanah mendekati 7.

Pada Tabel 1 menunjukkan nilai $\mathrm{pH}$ tanah hutan mangrove rata-rata 6,7 menunjukkan masih netral. Nilai pH merupakan ciri kimia tanah, menjadi faktor sangat penting dalam menentukan kesuburan tanah karena ketersedian unsur hara bagi tanaman sangat berkaitan dengan nilai $\mathrm{pH}$. Suhu udara rata-rata ditemukan sebesar $31^{\circ} \mathrm{C}$ ini menunjukkan bahwa pertumbuhan vegetasi hutan mangrove di Pantai Cengkrong cukup baik. Menurut Kusmana (1993) menyatakan bahwa pertumbuhan mangrove yang baik memerlukan suhu rata-rata minimal lebih besar dari $20^{\circ} \mathrm{C}$ dan perbedaan suhu musiman tidak melebihi $5^{0} \mathrm{C}$, kecuali di Afrika Timur dimana perbedaan suhu musiman mencapai $10^{\circ}$ C. Hutching dan Saenger (1987) mendapatkan kisaran suhu optimum untuk pertumbuhan beberapa spesies tumbuhan mangrove, yaitu Avicennia marina tumbuh baik pada suhu $18-20^{\circ}$ C, R. Stylosa, Ceriops ss., Excoeraria agallocha dan Luminitzera racemosa pertumbuhan tertinggi daun segar dicapai pada suhu 26-28 C. Lingkungan asin (beragaram) diperlukan untuk kestabilan ekosistem mangrove, seperti halnya banyak spesies yang kurang bersaing di bawah kondisi air tawar (Lugo, 1980). Tumbuhan mangrove tumbuh subur di daerah estuaria dengan salinitas 10 - 30 ppt. Salinitas hutan mangrove Pantai Cengkrong ditemuakan rata-rata $6,3 \mathrm{ppt}$ menunjukkan bahwa kadar salinitas terbilang rendah.salinitas dipengaruhi oleh pasang surut, curah hujan, penguapan, presipitasi dan topografi suatu perairan. Akibatnya, salinitas suatu perairan dapat sama atau berbeda dengan perairan lainnya, misalnya perairan darat, laut dan payau. Kisaran salinitas air laut adalah 30-35\%, estuari 5-35\% dan air tawar 0,5-5\% (Nyabakken, 1992). Kandungan subtrat pada hutan mangrove Pantai Cengkrong dikategorikan liat. Karakteristik subtrat merupakan faktor pembatas terhadap pertumbuhan mangrove.

Jumlah jenis yang ada pada kawasan hutan mangrove Pantai Cengkrong termasuk ke dalam kategori rendah dibandingkan jumlah total individu jenis mangrove yang terdapat di Indonesia yang mencapai 48 jenis dari 22 suku (Giesen 2006 dalam Purnomo dan Usmadi 2011). Dalam tiga dekade terakhir, Indonesia kehilangan 40\% mangrove (FAO, 2007). Artinya, Indonesia memiliki kecepatan kerusakan mangrove terbesar di dunia (Campbell dan Brown, 2015). Keragaman jenis yang rendah ini terjadi karena hutan mangrove yang berada di Pantai Cengkrong telah dilakukan rehabilitasi sejak tahun 2002- 2006 oleh Dinas Kelautan dan Perikanan (DKP) Kabupaten Trenggalek. Jenis tumbuhan mangrove yang digunakan untuk rehabilitasi sebanyak 4 spesies pioner yaitu Bruguiera gymnorrhiza, Rhizophora mucronata, Ceriops decandra, Xylocarpus granatum. Pantai cengkrong merupakan sebuah pantai yang hamparan di sekelilingi oleh hutan mangrove dengan 
luas 87 hektar. Menurut Purnomo dan Usmadi (2011), ekosistem yang kerap mengalami perubahan kondisi lingkungan akan menjadikan lingkungan tersebut mengarah pada kondisi lingkungan homogen. Keragaman jenis yang rendah pada kawasan ini dapat juga terjadi karena adanya perubahan lingkungan dan hadirnya ekowisata hutan mangrove di Pantai Cengkrong, terkait dengan UU No. 31 Tahun 2004 tentang perikanan, UU No. 27 Tahun 2007 tentang kelestarian lingkungan dan khusus untuk Kabupaten Trenggalek, terdapat Peraturan Daerah No. 10 Tahun 2004 tentang pengelolaan sumber daya perikanan. Peraturan tersebut ditetapkan dengan maksud untuk melestarikan ekosistem hutan mangrove. Kondisi ini ditunjukkan dengan nilai salinitas sekitar 6,3 ppt termasuk kedalam kategori rendah.

Kawasan mangrvoe Pantai Cengkrong merupakan jenis tanah liat dengan jenis mangrove yang mendominansi yaitu zona I S. alba, zona II A.alba, dan zona III L. racemosa. Namun, tinggi penggenangan air laut pada kawasan ini berbeda. Secara umum, zona yang paling dekat dengan laut (berhadapan langsung dengan laut) didominasi oleh jenis-jenis Avicennia dan Sonneratia. Sedangkan zona pertengahan biasanya didominasi oleh jenis-jenis Rhizopora dan kadang juga ditemui jenis Bruguiera. Zona yang paling dekat dengan daratan biasanya didominasi oleh jenis-jenis Bruguiera, Ceriops, Xylocarpus dan Lumnitzera. Soerianegara dan Indrawan (2002) menyatakan salah satu aspek yang mempengaruhi suatu ekosistem adalah lingkungannya. Walaupun spesies mangrove dapat tumbuh pada salinitas yang ekstrem atau sangat tinggi, namun biasanya pertumbuhannya kurang baik atau pendek-pendek, bahkan beberapa spesies ada yang tidak tahan pada salinitas yang tinggi (Supriharyono, 2000). Pasang surut air laut pada kawasan ini cukup mempengaruhi pertumbuhan ekosistem mangrove. Dikarenakan jenis $S$. alba dan A. alba merupakan tanaman mangrove jenis pionir.

Kondisi vegetasi mangrove yang ada menunjukkan bahwa kelimpahan vegetasi mangrove dapat digambarkan dalam nilai kerapatan jumlah individu pohon per satuan luas. Kerapatan mangrove merupakan salah satu indikator tingkat kerusakan suatu kawasan mangrove yang dikategorikan dalam tiga keteria yaitu kriteria sangat padat $\geq 1500$ batang/ha, padat $\geq 1000-<1500$ batang/ha, dan jarang $<1000$ batang/ha (KMLH No.201 Tahun 2004). Analisis kawasan hutan mangrove Pantai Cengkrong tergolong kriteria jarang karena nilai kerapatan yang dimiliki jenis A. alba sebesar 100. Kerapatan vegetasi mangrove ini menunjukkan kemampuan tumbuh dan berkembang biak suatu jenis di lokasi tertentu. Kawasan mangrove Pantai Cengkrong yang kerapatannya didominansi oleh $S$. alba menunjukkan bahwa jenis ini mampu beradaptasi dengan kondisi lingkungan.

Kondisi mangrove pada dasarnya dipengaruhi oleh pengaruh pasang surut air laut, namun pada kawasan hutan mangrove Pantai Cengkong air laut muda masuk kedalam kawasan. Kemampuan adaptasi dari tiap jenis terhadap keadaan lingkungan menyebabkan terjadinya perbedaan komposisi hutan mangrove dengan batasbatas yang khas. Hal ini menjadi salah satu penyebab kondisi zonasi vegetasi mangrove yang tidak optimal dan diakibatkan adanya pengaruh dari kondisi tanah, kadar garam, lamanya penggenangan dan arus pasang surut. Sehingga kondisi yang ditunjukkan pada pola zonasi yang terbentuk tidak sesuai dengan zonasi mangrove yang seharusnya. Menurut Suprajaka et al. (2005) zonasi mangrove yang tidak stabil. Ketidak stabilan kondisi ekosistem mangrove yang terjadi pada kawasan hutan mangrove Pantai Cengkrong dikarenakan dilakukan reabilitasi sejak tahun 2002 yang dilakukan tanpa mengetahui kesesuain jenis lokasi dan faktor alam yang membawa buah jatuh saat pasang surut air laut sehingga pertumbuhan tidak stabil.

Pembentukan zonasi hutan mangrove Pantai Cengkrong bisa dikatakan sesuai dengan pembagian zonasi menurut Bengen (2004) zona garis pantai, yaitu kawasan yang berhadapan langsung dengan laut biasanya ditemukan jenis Rhizophora stylosa, $R$. Mucronata, Avicennia marina dan Sonneratia alba. Zona tengah merupakan kawasan yang terletak di belakang zona garis pantai dan memiliki lumpur liat. Biasanya ditemukan jenis Rhizophora apiculata, Avicennia officinalis, Bruguiera cylindrica, $B$. gymnorrhiza, B. parviflora, B. sexangula, Ceriops tagal, Aegiceras corniculatum, Sonneratia caseolaris dan Lumnitzera littorea. Zonasi belakang, yaitu kawasan yang berbatasan dengan hutan darat. Jenis tumbuhan yang biasanya muncul antara lain Acanthus ebracteatus, A. ilicifolius, Acrostichum aureum, A. speciosum. Jenis mangrove yang tumbuh adalah Heritiera littolaris, Xylocarpus granatum, Excoecaria agalocha, Nypa fruticans, Derris trifolia, Osbornea octodonta dan beberapa jenis tumbuhan yang biasa berasosiasi dengan mangrove antara lain Barringtonia asiatica, Cerbera manghas, Hibiscus tiliaceus, Ipomea pes-caprae, Melastoma candidum, Pandanus tectorius, Pongamia pinnata, Scaevola taccada dan Thespesia populnea. Dikarenakan masih ditemukan jenis-jenis mangrove setiap pembagian zonasi.

\section{Kesimpulan}

Berdasarkan hasil penelitian yang telah dilakukan terhadap zonasi dan komposisi vegetasi mangrove di Desa Karanggandu Pantai Cengkrong ditemukan jenis mangrove sebanyak 12 (dua belas) jenis mangrove sejati yaitu Avicennia alba, Bruguiera gymnorrhiza, Bruguiera parfiflora, Ceriops decandra, Ceriops tagal, Lumnitzera racemosa, Rhizophora apiculata, Rhizophora mucronata, Sonneratia alba, Sonneratia caseolaris, Xylocarpus granatum dan Nypa fruticans.

Sedangkan, zonasi mangrove menunjukan bahwa pada zona I atau zona terbuka ditumbuhi oleh Sonneratia alba dan dapat dijumpai Rhizophora mucronata, Ceriops decandra dengan salinitas 6 ppt. Zona II atau zona tengah ditumbuhi oleh jenis Avicennia alba dan dapat dijumpai Sonneratia alba, Xylocarpus granatum dengan salinitas 6 ppt. Zona III atau zona dalam yang lebih dekat dengan ke arah darat 
ditumbuhi oleh jenis Xylocarpus granatum dan dapat dijumpai Lumnitzera racemosa, Bruguiera parviflora dengan salinitas 4 ppt. Hal ini menunjukan bahwa disetiap zonasi masih ditemukan jenis spesies yang sama dikarenakan faktor alam dan pasang surut air laut sehingga buah yang jatuh akan terbawa dan tumbuh dibeberapa zona mangrove.

Dari hasil pengukuran nilai parameter lingkungan seperti $\mathrm{pH}$ tanah, suhu udara, salinitas dan subtrat didapatkan nilai rata-rata $\mathrm{pH}$ tanah 6,7 , suhu udara 31 , salinitas 5,3 ppt dan kondisi subtrat tergolong liat. Dari kategori nilai penelitian diatas menunjukan bahwa kondisi lingkungan yang berada di Desa Karanggandu Pancer Cengkrong tergolong baik untuk pertumbuhan hutan mangrove.

\section{Ucapan Terima Kasih}

Ucapan terima kasih disampaikan kepada Bupati Trenggalek, Dinas Kelautan Perikanan (DKP), Kepala Desa Karanggandu dan kelompok POKMASWAS yang telah memberikan izin pemakaian lokasi hutan mangrove Pantai Cengkrong sebagai tempat penelitian sehingga mambantu dalam kelancaran penelitian ini.

\section{Daftar Pustaka}

[1] [KLH] Kementrian Negara Lingkungan Hidup. 1993. Kumpulan peraturan pengendalian kerusakan pesisir dan laut. Deputi bidang Peningkatan Konservasi Sumberdaya Alam dan Pengendalian Kerusakan Lingkungan.

[2] Anonim, 2006. Ekologi Ajar Ekologi Tumbuhan.file://D//Elearning/EKOLOGI\%20\%20TUMBU HAN/Textbook/BAHAN\%20AJAR.html (62 of 105) 5/8/2007. Diakses tanggal 4 Mei 2017.

[3] Anwar, J., S.J. Damanik, N. Hisyam dan A.J. Whitten, 1984 Ekologi ekosistem Sumatra. Gajah Mada Universitay Press, Yogyakarta.

[4] Badan Pusat Statistik, 2016. Kecamatan Watulimo dalam Angka 2016. Trenggalek, Badan Pusat Statistik.

[5] Bengen, D.G., 2004. Mengenal dan Memelihara Mangrove. Pusat Kajian Sumber Daya Pesisir dan Lautan IPB, Bogor.

[6] Bunt, J.S. dan W.T. Williams, 1981. Vegetational Relationships in The Mangroves of Tropical Australia. Marine Ecology Progress Series. 4, pp. 349-359.

[7] Cambell, A., dan B. Brown, 2015. Indonesia vast mangroves are a treasure worth saving.TheConversation.From:http://theconversation.com/in donesia-vast-mangroves-area-a-treasure-worth-saving33367.

[8] Chandra, I.A., G. Seca, dan A.M.K. Hena, 2011. Aboveground Biomass Production of Rhizophora apiculata Blume in Sarawak Mangrove Forest. Agricultural and Biological Sciences, 6 (4), 469-474.

[9] Chapman, V.J (editor), 1977. Wet Coastal Ecosystems. Ecosystems of the World: 1. Elsevier Scientific Publishing Company, p. 428.

[10] Ding, H., 1958. Rhizophoraceae. Flora Malesiana, Ser.I. 5, 429-493.
[11] FAO, 2007. The World's Mangroves 1980-2005. Forest Resources Assement Working Paper No.153. Food and Agriculture Organization of The United Nations. Rome, FAO.

[12] Hutching, P. and P. Saenger, 1987. Ecology of Mangrove. University of Queensland Press, Australia.

[13] Jamili, 1998. Distribusi Frekuensi Diameter Batang Dan Zonasi Mangrove Hubungannya Dengan Faktor Lingkungan di Pantai Napabalano Sulawesi Tenggara. Tesis. Program Pascasarjana Universitas Gajah Mada, Yogyakarta.

[14] Kint, A., 1934. De luchtfoto en de topografisch terreingesteldheid in de mangrove. De Tropische Natuur. 23, pp. 173-189.

[15] Komiyama, A., H. Moriya, S. Prawiroatmodjo, T. Tomi dan K. Ogini. 1988. Forest as an Ecosystem, Its Structure and Function; 1: Floristic Composition and Stand Structure. Dalam Biological System of Mangroves. Laporan Ekspedisi.

[16] Krebs, C.J., 1972. The Experimental Analysis of Distribution and Abundance. New York, Harper International.

[17] Kusmana, C., 1995. Manajemen hutan mangrove Indonesia Bogor, IPB Press.

[18] Kusmana, C., 1995. Pengembangan Sistem Silvikultur Hutan Mangrove dan Alternatifnya. Rimba Indonesia XXX No. 12. pp. $35-41$

[19] Kusmana, C., Onrizal, Sudarmadji, 2003. Jenis-Jenis Pohon Mangrove di Teluk Bintuni, Papua. Bogor, IPB Press.

[20] Lugo dan Snedeker, 1980. Mangrove Ecosystem: Successional or steadt state. Biotropic. 12, 67-75.

[21] Madiana, S., C. Muryani, S. Santoso, 2016. Kajian Perubahan Luas dan Pemanfaatan Serta Persepsi Masyarakat Terhadap Pelestarian Hutan Mangrove di Kecamatan Teluk Ambon Baguala. Jurnal GeoEco. 2(2), pp.170-183.

[22] Masserschmidt, J.W., 1995. Managing to kill: Masculinities and thr space shuttle Challenger explosion. Masculinities. 3 (4), pp. 1-22.

[23] Noor, R.Y., M. Khazali, dan I.N.N. Suryadiputra, 1999. Panduan Pengenalan Mangrove di Indonesia. PKA/WI-IP, Bogor.

[24] Noor, Y.R., M. Khazali, dan I.N.N. Suryadiputra, 2012. Panduan Pengenalan Mangrove Indonesia. Bogor, Perlindungan hutan konservasi alam WI-IP.

[25] Nybakken, J.W., 1992. Biologi Laut: Suatu Pendekatan Ekologis. Eidman, M., Koesoebiona, D.G. Begen. M. Hutomo, dan S. Sukardjo [Penerjemah]. Terjemahan dari: Marine Biology: An Ecological Approach. Jakarta, PT. Gramedia.

[26] Purnomo, D.W., D. Usmadi, 2011. Sebaran keragaman dan kelimpahan vegetasi mangrove di pulau Batam, Karimun, Natuna, dan pulau-pulau kecil sekitarnya. Seminar Nasional HUT Kebun Raya Ciboda Ke-159. pp. 21-28. [27 Februari 2017].

[27] Samingan, M.T., 1980. Notes on The Vegetation of The Tidal Areas of South Sumatra, Indonesia, with Special Reference to Karang Agung. Dalam International Social. Tropical Ecologi, Kuala Lumpur. hal. 1107-1112.

[28] Soerinegara, I., A. Indrawan, 2002. Ekologi Hutan Indonesia. Bogor, Institut Pertanian Bogor.

[29] Suprajaka, A. Poniman, Suhartono, 2005. Konsep dan model penyusunan tipologi pesisir Indonesia menggunakan teknologi Sistem Informasi Geografi. Malaysian Journal of Society and Space. 1, pp. 76-84.

[30] Supriharyono, 2000. Pelestarian dan Pengelolahan Sumberdaya Alam di Wilayah Pesisir Tropis. Jakarta, Gramedia Pustaka Utama.

[31] Van Steenis, C.G.G.J., 1958. Ecology of Mangroves. Introduction to Account of the Rhizophoraceae by Ding Hou, Flora Malesiana, Ser. I. 5, pp. 431-441. 